\title{
Estimation of the 10-Year Risk of Fatal Cardiovascular Disease in the Portuguese Population: Results from the First Portuguese Health Examination Survey (INSEF 2015)
}

\section{Estimativa do Risco a 10 Anos de Doença Cardiovascular Fatal na População Portuguesa: Resultados do $1^{\circ}$ Inquérito Nacional de Saúde com Exame Físico (INSEF 2015)}

\author{
Vânia GAIO $\square^{1,2}$, Ana Paula RODRIGUES ${ }^{1}$, Irina KISLAYA ${ }^{1,2}$, Marta BARRETO ${ }^{1,2}$, Sónia NAMORADO ${ }^{1}$, \\ Carlos Matias DIAS 1,2
}

Acta Med Port 2020 Nov;33(11):726-732 - https://doi.org/10.20344/amp.13009

\section{ABSTRACT}

Introduction: Cardiovascular disease is the leading cause of morbidity and mortality in Portugal and globally. Cardiovascular risk algorithms, namely the SCORE (Systematic Coronary Risk Evaluation), are recommended in the context of cardiovascular disease prevention. Our aim is to estimate and characterize the cardiovascular risk of the Portuguese population aged between 40 and 65 years old, in 2015, using the SCORE algorithm.

Material and Methods: This study was performed on a subsample of the first Portuguese National Health Examination Survey INSEF, including all participants between 40 and 65 years old with available data on sex, age, smoking status, total cholesterol and systolic blood pressure $(n=2945)$. The prevalence of the cardiovascular risk categories were stratified by sex, age group, marital status, educational level, occupational activity, urbanization of living area, region and income.

Results: In 2015 , about $5.1 \%$ and $11.9 \%$ of the Portuguese resident population aged between 40 and 65 years old were, respectively, at high and very high risk of having a fatal CV event in the following 10 years. The highest prevalence of very high cardiovascular risk was found in males, individuals aged 60-65 years old, married or living with someone, without any formal education or just with the $1^{\text {st }}$ cycle of basic education and belonging to the less skilled category of the occupational activity ( $\mathrm{C}$ category) in comparison with the other corresponding groups.

Discussion: A previous national study found a similar proportion of the population at high/very high cardiovascular risk (19.5\% versus $17.1 \%)$. Our study is representative of the adult Portuguese population and adopted the European Health Examination Survey procedures, which are essential for future comparisons with other European countries. Some of the limitations of this study include the possible participation bias and the non-calibration of the SCORE algorithm for the Portuguese population.

Conclusion: In 2015, a considerable proportion of the Portuguese population aged between 40 and 65 years old had a high or very high risk of developing a fatal cardiovascular event in the next 10 years. Due to the possible overestimation of the cardiovascular risk already reported in other European countries, it will be important to carry out a follow-up study to validate the adequacy of using the SCORE algorithm in the Portuguese population.

Keywords: Cardiovascular Diseases; Portugal; Risk Assessment; Risk Factors; Socioeconomic Factors

\section{RESUMO}

Introdução: A doença cardiovascular é a principal causa de morbilidade e mortalidade a nível global e em Portugal. A utilização de algoritmos de avaliação do risco cardiovascular, nomeadamente o SCORE (Systematic Coronary Risk Evaluation), é recomendada no contexto da prevenção destas doenças. O objetivo deste estudo é estimar e caracterizar o risco cardiovascular na população portuguesa com idade compreendida entre os 40 e os 65 anos, em 2015, utilizando o algoritmo SCORE.

Material e Métodos: Para o cálculo do risco cardiovascular foram considerados os participantes no Inquérito Nacional de Saúde com Exame Físico (INSEF), com idades entre os 40 e os 65 anos de idade, com dados disponíveis sobre sexo, idade, consumo de tabaco, colesterol total e pressão arterial sistólica $(n=2945)$. A prevalência das categorias de risco cardiovascular foi estratificada de acordo com o sexo, grupo etário, estado civil, escolaridade, ocupação, grau de urbanização, região e rendimento.

Resultados: Em 2015, 5,1\% e 11,9\% da população residente em Portugal com idades entre os 40 e os 65 anos tinha, respetivamente, um risco elevado e um risco muito elevado de ter um evento cardiovascular fatal nos 10 anos seguintes. A maior prevalência de risco cardiovascular muito alto foi encontrada nos homens, nos indivíduos do grupo etário dos 60 aos 65 anos, casados ou vivendo conjugalmente, sem escolaridade ou apenas com o primeiro ciclo do ensino básico e pertencentes à categoria menos qualificada da atividade ocupacional (categoria C).

Discussão: Um estudo nacional anterior encontrou uma percentagem semelhante da população com um risco elevado/muito elevado de ter um evento cardiovascular fatal (19,5\% versus 17,1\%). O nosso estudo é representativo da população portuguesa adulta e adotou os procedimentos do Inquérito Europeu de Saúde com Exame Físico, essencial para futuras comparações com outros países europeus. Algumas das limitações do presente estudo incluem o possível viés de participação e a não calibração do algoritmo SCORE

1. Departamento de Epidemiologia. Instituto Nacional de Saúde Doutor Ricardo Jorge. Lisboa. Portugal.

2. Escola Nacional de Saúde Pública. Centro de Investigação em Saúde Pública. Universidade NOVA de Lisboa. Lisboa. Portugal.

$\square$ Autor correspondente: Vânia Gaio. vania.gaio@insa.min-saude.pt

Recebido: 24 de outubro de 2019- Aceite: 29 de janeiro de 2020 | Copyright @ Ordem dos Médicos 2020 
para a população portuguesa.

Conclusão: Uma percentagem considerável da população portuguesa com idade entre os 40 e os 65 anos tinha, em 2015 , um risco alto ou muito alto de desenvolver um evento cardiovascular fatal nos 10 anos seguintes. Dada a possibilidade de sobrestimação de risco, já reportada para outros países Europeus, seria essencial realizar um estudo de follow-up para validar a adequação do uso do SCORE na população portuguesa.

Palavras-chave: Avaliação do Risco; Doença Cardiovascular; Factores de Risco; Factores Socioeconómicos; Portugal

\section{INTRODUCTION}

Cardiovascular disease (CVD) continues to be the leading cause of morbidity and mortality worldwide. In 2015, according to the Global Burden of Disease study, there were 422.7 million new cases of CVD (95\% Cl: 415.5 - 427.9 million) and 17.9 million CVD deaths (95\% Cl: $17.6-18.3$ million) worldwide. ${ }^{1}$ In Portugal, CVD is also the main cause of morbidity and mortality, having led to 32443 deaths in 2015 (29.8\% of the total mortality). ${ }^{2}$

A significant proportion of CVD morbidity and mortality is preventable through the reduction of cardiovascular (CV) risk factors, namely elevated blood pressure, hypercholesterolemia, diabetes, physical inactivity, obesity, unhealthy diet and smoking. ${ }^{3}$ Consequently, effective preventive measures based on these modifiable risk factors both in people without established CVD (primary prevention) as well as in people with confirmed CVD (secondary prevention) are an important public health strategy in order to reduce CVD burden. ${ }^{4}$

In this context, guidelines on CVD prevention in clinical practice recommend the assessment of total $\mathrm{CV}$ risk through the use of risk score algorithms that incorporate multiple CV risk factors to estimate the CV risk for each individual. 5 Presently, many risk assessment tools are available for use in the general population..$^{7-11}$ One of them, recommended since 2003 by the European Guidelines on CVD prevention in clinical practice, is SCORE (Systematic Coronary Risk Evaluation). ${ }^{8}$ The SCORE algorithm was developed using prospective data from 12 European cohorts and estimates the 10-year risk of a fatal CV event in individuals aged between 40 and 65 years old without pre-existing $\mathrm{CVD}^{8}$. There are two SCORE versions created for high and low risk European countries, with Portugal being considered a low-risk European country. ${ }^{8}$ The risk factors used by this algorithm are age, sex, smoking, blood cholesterol and systolic blood pressure values. Some European countries have already estimated and validated the SCORE algorithm for their populations. ${ }^{12-14}$

In Portugal, the guideline 005/2013 of the DirectorateGeneral of Health (DGS) recommends the use of SCORE to assess the CV risk in both primary care and secondary care. ${ }^{15}$ Studies estimating the CV risk in the Portuguese population are scarce and performed mainly on specific subpopulations. ${ }^{16-19}$ The main aim of the present study is to estimate and characterize the 10 -year risk of fatal cardiovascular disease for the Portuguese population aged between 40 and 65 years old, in 2015, using the SCORE algorithm.

\section{MATERIAL AND METHODS \\ Study population}

This study was performed using data from the first Portuguese National Health Examination Survey (INSEF). A detailed description of the methodology and procedures has been previously published. ${ }^{20}$ Briefly, INSEF was a crosssectional population-based survey led by the National Institute of Health Doutor Ricardo Jorge (INSA) in partnership with the five Regional Health Administrations from mainland Portugal, the two Regional Health Secretariats from the Autonomous Regions of Azores and Madeira and the Norwegian Institute of Public Health, in 2015. The INSEF survey included three components: physical examination (blood pressure, height, weight, waist and hip circumference), blood collection to perform laboratory tests (total cholesterol, HDL, LDL and triglycerides, $\mathrm{HbA} 1 \mathrm{c}$ and full blood count) and an interview using a structured health questionnaire.

The INSEF target population consisted on non-institutionalized individuals aged between 25 and 74 years old, living in Portugal for more than 12 months, who were able to follow an interview in Portuguese. The INSEF sample ( $\mathrm{n}$ $=4911$ ) was selected through complex multistage probabilistic design in order to be representative of the Portuguese population at national and regional levels. ${ }^{20}$ For this study, the analysis was restricted to the subsample of INSEF participants aged between 40 and 65 years old with data available on sex, age, smoking status, total cholesterol and systolic blood pressure $(n=2945)$. From the 2993 INSEF participants aged between 40 and 65 years old $(60 \%$ of the INSEF sample), only $1.6 \%(n=48)$ did not have data in each of the enumerated variables.

\section{Study variables and measurements}

Blood pressure (BP) was measured according to the European Health Examination Survey (EHES) procedures. ${ }^{21}$ using an automated blood pressure measurement device (OMROM M6) during the physical examination after a fiveminute rest in a sitting position. Three consecutive BP readings were taken on the right arm with a one-minute interval between each two measurements and an average of the second and third readings of BP measures was performed.

Total cholesterol was measured in fresh non-fasting serum samples, through the cholesterol esterase/oxidase method. This measurement was performed in the 12 regional collaborating laboratories that participated in the $\mathrm{Na}-$ tional Program for External Laboratory Quality Assessment (PNAEQ) in 2015 to ensure comparability and reliability of blood tests results. 
Smoking status was assessed through the question "Do you smoke?". Individuals who reported to "smoke daily" or "smoke occasionally" were considered smokers. Remaining study variables (sex, age, educational level, marital status, occupation, income) were also self-reported throughout the interview.

Those participants who reported to have been diagnosed by a healthcare professional and, or, those on antidiabetic medication were considered as having diabetes.

\section{Estimation of cardiovascular risk}

The low-risk version of the SCORE algorithm was used to estimate the 10-year risk of a fatal CV event in the Portuguese population ${ }^{8}$ based on age, sex, smoking, total cholesterol and systolic blood pressure values. Accordingly, very high risk was considered when the score was $\geq 10 \%$, high risk was considered when the score was $\geq 5 \%$ and < $10 \%$, moderate risk was considered when the score was $\geq$ $1 \%$ and $<5 \%$ and low risk was considered when the score was $<1 \%$.

Participants having both diabetes and any other risk factor and participants having reported a previous CV event (Myocardial infarction or Stroke) were a priori considered to be at very high risk, regardless of the score value.

\section{Statistical analysis}

The statistical analysis was performed using the [SVY] package of Stata $15.1^{\circledR}$ software.22 The significance level for all analysis was set at $5 \%$. Descriptive statistics (percentages and confidence intervals) were used to provide characterization of the CV risk categories. The prevalence of $\mathrm{CV}$ risk categories (low, moderate, high and very high) was estimated stratifying by 1) sex (female, male); 2) age group (40 - 44, 45 - 49, 50 - 54, 55 - 59, 60 - 65); 3) marital status (married/living together as a couple, unmarriedsingle/divorced/separated/widow); 4) educational level (no schooling/ $1^{\text {st }}$ cycle of basic education, $2^{\text {nd }} / 3^{\text {rd }}$ cycle of basic education, secondary school and higher education); 5) occupational activity (A-Armed forces, Managers, Professionals; B-Technicians \& Associate Professionals, Clerical Support Workers, Services \& Sales Workers; C-Skilled Agricultural Workers, Craft \& Related Trades Workers, Plant \& Machine Operators, Elementary occupations, Housewifes and Students); 6) urbanization of living area (urban, ruralaccording to the TIPAU classification, the urban medium areas and predominantly rural areas correspond to the rural stratum, while predominantly urban area corresponds to the urban stratum); 7) health region (North, Centre, Lisbon and Tagus Valley (LVT), Alentejo, Algarve, Autonomous Region of the Azores - RAA, Autonomous Region of Madeira - RAM) and 8) adult equivalized income ${ }^{23}(<€ 428, € 428$ - €609, €610 - €799, €800 - €1109, z€1110). The designadjusted version of chi-square test was used to compare CVD risk distribution among population subgroups.

All estimates were weighted to account for different selection probabilities resulting from complex sample design and to match the population distribution in terms of geo- graphic region, age group and sex in 2015 . The $95 \%$ confidence intervals for the presented estimates were calculated using a logit transformation.

\section{Ethical issues}

The INSEF study received approval from the Ethics Committee of the Portuguese National Institute of Health Doutor Ricardo Jorge, the National Data Protection Authority and from eight regional Ethics Committees. All participants provided informed consent before data collection.

\section{RESULTS}

\section{Participants' characteristics}

Of 2945 INSEF participants aged between 40 and 65 years old included in this study, 1592 (52.9\%) were female. Most of participants were living in urban areas (72.9\%), $76.6 \%$ were married or living as a couple, $30.7 \%$ had no formal education or only the $1^{\text {st }}$ cycle of basic education, $37.0 \%$ had a monthly income below $€ 428$, and $42.4 \%$ belonged to the $\mathrm{C}$ category of the occupational activity (Table $1)$.

\section{CV risk characterization}

In 2015, 11.9\% (95\% Cl: 10.1 - 14.0) of the Portuguese population aged between 40 and 65 years old, had a very high CV risk (SCORE $\geq 10 \%), 5.1 \%(95 \% \mathrm{Cl}: 4.2-6.3)$ had a high CV risk (SCORE $\geq 5 \%$ and < 10), 74.9\% (95\% Cl: 72.9 - 76.7) had a moderate CV risk (SCORE $\geq 1 \%$ and < $5 \%$ ) and $8.1 \%(95 \% \mathrm{Cl}$ : 6.5 - 10.0) had low CV risk (SCORE $<1 \%$ ) (Table 2). SCORE $\geq 5 \%$ (very high/high risk) was obtained for $17.1 \%(95 \% \mathrm{Cl}: 15.1-19.3)$ of the study population, of which about $21.6 \%$ (95\% Cl: 14.9 - 30.3) reported no previous $\mathrm{CV}$ events.

The prevalence of the very high $\mathrm{CV}$ risk category was higher among males [15.6\% (95\% Cl: 12.5 - 19.4)] than females [8.6\% (95\% Cl: $6.8-10.7)]$ and in participants aged between 60 and 65 years old [25.6\% (95\% Cl: 22.2 - 29.2)] when compared to participants from the other age groups. Moreover, the very high $\mathrm{CV}$ risk category was more frequent in married participants [12.6\% (95\% Cl: $10.5-15.0)]$, in participants with no schooling or just the $1^{\text {st }}$ cycle of basic education [20.1\% (95\% Cl: 17.3 - 23.3)] and belonging to the $\mathrm{C}$ category of the occupational activity $[14.1 \%(95 \% \mathrm{Cl}$ : 11.6 - 17.0)]. As for urbanization of urban area, region and income, no statistically significant differences were found between the different categories of these variables. Similar results were found concerning the sociodemographic characterization of the participants from the high $\mathrm{CV}$ risk category (Table 2).

\section{DISCUSSION}

These results show that, in 2015 , about $5.1 \%$ and $11.9 \%$ of the Portuguese resident population aged between 40 and 65 years old were at high or very high risk, respectively, of having a fatal $\mathrm{CV}$ event in the following 10 years. The highest prevalence of very high $\mathrm{CV}$ was found in males, individuals aged between 60 and 65 years old, married, with 
no schooling or just the $1^{\text {st }}$ cycle of basic education and belonging to the $\mathrm{C}$ category of the occupational activity classification.

Results from a previous study performed only in the Mainland Portuguese Population, in 2005/2006 ${ }^{16}$ show a

Table 1 - Socio-demographic characteristics of participants in the first National Health Examination Survey in Portugal (INSEF 2015)

\begin{tabular}{lcc}
\hline Variable & $\mathbf{n}$ & \% weighted \\
\hline Sex & & \\
Women & 1592 & 52.9 \\
Men & 1353 & 47.1
\end{tabular}

\section{Age group}

$\begin{array}{lll}40-44 \text { years } & 602 & 21.4 \\ 45-49 \text { years } & 564 & 19.4 \\ 50-54 \text { years } & 610 & 20.3 \\ 55-59 \text { years } & 531 & 16.9 \\ 60-65 \text { years } & 638 & 22.0\end{array}$

Marital Status*

Not Married

Married

\section{Educational level}

No schooling $/ 1^{\text {st }}$ cycle of basic education

$2^{\text {nd }}$ and $3^{\text {rd }}$ cycle of basic education $\quad 1065$

30.7

Secondary school

Higher education

\section{Occupational activity**}

\section{A}

B

C

\section{Income}

$$
<€ 428
$$

\section{Region}

North

Centre

\section{Alentejo}

Azores

Urbanization of living area

Rural

* Married: married or living together; Not married: single, divorced/separated and widow; ** A-armed forces, managers, professionals; B-technicians \& associate professionals, clerical support workers, services \& sales workers; C-skilled agricultural workers, craft \& related trades workers, plant $\&$ machine operators, elementary occupations, housewives, students. proportion of the population aged between 40 and 65 years old at high $\mathrm{CV}$ risk similar to the one obtained in the present study (19.5\% versus $17.1 \%)$. Despite some methodological differences between the studies, we found a lower estimate in comparison with the Spanish $(22.8 \% \text { in } 2009-2010)^{24}$ and Italian populations $(26.0 \% \text { in } 2015)^{25}$, which are also considered low-CV risk countries just like Portugal.Men and older adults were at higher $\mathrm{CV}$ risk and these results are corroborated by other national and international authors. ${ }^{16,26}$ Regarding the $\mathrm{CV}$ risk of the older age group (60 - 65 years), it is important to point out that SCORE probably overestimates the risk because, based on SCORE, the weight of the age factor leads to higher absolute risk estimates given.

$\mathrm{CV}$ risk was associated with lower education and elementary occupations but not with income, in the Portuguese population. The relationship between high $\mathrm{CV}$ risk and income categories seemed to be U-shaped, with higher proportion of high-risk individuals on the extremes of income distribution. At European level, few studies have focused on the socioeconomic distribution of CV risk estimated using the SCORE algorithm and their results are not consistent. Previous research found no statistically significant educational gradient of CV risk in Portugal. ${ }^{16}$ Higher CV risk among the more socioeconomically deprived groups was previously described for the general population in Poland. ${ }^{26}$ In Germany, similar results were observed for women but not for men. ${ }^{27}$ However, differences in indicators used do assess socioeconomic status do not allow direct comparisons of estimates to be made with our study because they used composite socioeconomic status indicators.

Strengths of the present study include representativeness at regional and national level of the adult Portuguese population and the adoption of the European Health Examination Survey procedures, namely for BP measurement, essential for future comparisons with other European countries. $^{21}$

Some of the limitations of this study include the possible participation bias due to the final participation rate (43.9\%). Moreover, we used the original SCORE algorithm that has not been yet calibrated for the Portuguese population. Moreover, correction of the risk score for the participant's deprived socioeconomic status was not performed for this study, although recommended in the guideline 005/2013 of the Directorate-General of Health (DGS). On the other hand, there is some possibility of overestimation of the CV risk based on the SCORE calculation in our study. In fact, some studies from other European countries showed that the SCORE algorithm largely overestimates the true risk of a fatal CV event. ${ }^{28-30}$ Consequently, its calibration is essential to better predict the rates of $\mathrm{CV}$ mortality. Considering that this risk refers to the development of a fatal CV event in the following 10 years, it will be important to carry out a follow-up study to validate the adequacy of SCORE use in the Portuguese population.

\section{CONCLUSION}

The number of participants at high or very high CV risk 
Table 2 - Distribution of the SCORE risk categories according to sex, age group, region, marital status, educational level, occupational activity, urbanization of living area, health region and income in the Portuguese population according to data from the First Health Examination Survey (INSEF 2015)

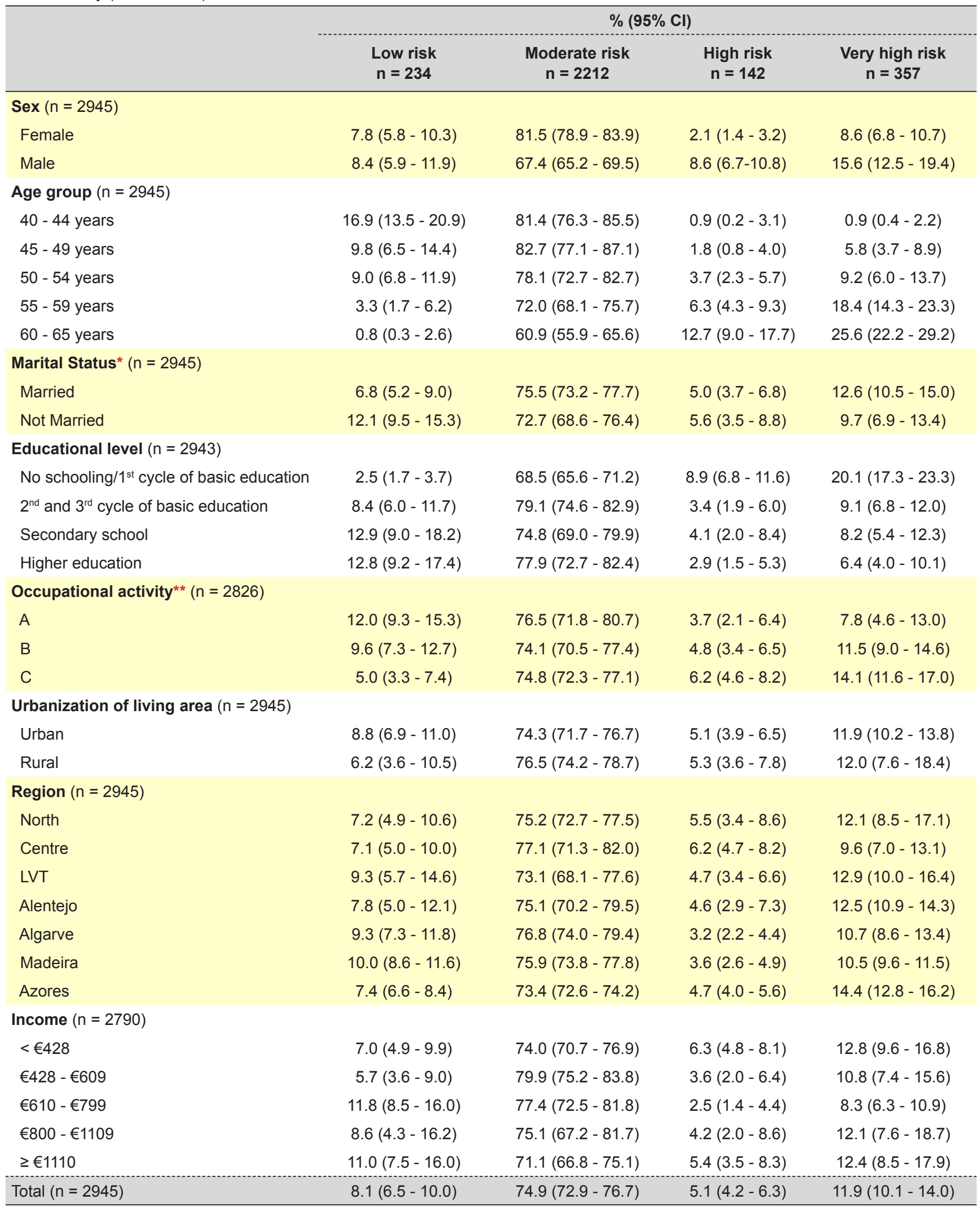

All estimates were weighted to account for survey sampling design. ${ }^{*}$ Married: married or living together; Not married: single, divorced/separated and widow; ${ }^{* *}$ A-srmed forces, managers, professionals; B-technicians \& associate professionals, clerical support workers, services \& sales workers; C-skilled agricultural workers, craft \& related trades workers, plant \& machine operators, elementary occupations, housewives, students. 
is a general public health concern and the INSEF results suggest that some subgroups are particularly vulnerable, namely males and older adults from more socioeconomically deprived groups.

Correctly identifying people with an elevated CV risk at an early stage and the adoption of appropriate preventive strategies is an important step to reduce CVD mortality in the Portuguese population. The application of $\mathrm{CV}$ risk prediction models like SCORE could be a good tool to achieve this goal, but it is essential to validate its adequacy in the Portuguese population.

\section{ACKNOWLEDGEMENTS}

The authors are grateful to all the professionals involved in the INSEF fieldwork and to all the INSEF participants.

\section{PROTECTION OF HUMANS AND ANIMALS}

The authors declare that the procedures were followed according to the regulations established by the Clinical Research and Ethics Committee and to the 2013 Helsinki Dec- laration of the World Medical Association.

\section{DATA CONFIDENTIALITY}

The authors declare having followed the protocols in use at their working center regarding patients' data publication.

\section{CONFLICTS OF INTEREST}

The authors declare that there is no conflict of interests regarding the publication of this paper.

\section{FUNDING SOURCES}

The Portuguese National Health Examination Survey was developed as part of the project "Improvement of epidemiological health information to support public health decision and management in Portugal. Towards reduced inequalities, improved health, and bilateral cooperation", that benefits from a $€ 1,500,000$ Grant from Iceland, Liechtenstein and Norway through the EEA Grants.

\section{REFERENCES}

1. Roth GA, Johnson C, Abajobir A, Abd-Allah F, Abera SF, Abyu G, et al. Global, regional, and national burden of cardiovascular diseases for 10 causes, 1990 to 2015. J Am Coll Cardiol. 2017;70:1-25.

2. Instituto Nacional de Estatística. Causas de Morte 2015. Lisboa: INE; 2017.

3. Bundhun PK, Wu ZJ, Chen MH. Impact of modifiable cardiovascular risk factors on mortality after percutaneous coronary intervention: a systematic review and meta-analysis of 100 studies. Medicine. 2015;94:e2313.

4. Hobbs FD, Piepoli MF, Hoes AW, Agewall S, Albus C, Brotons C, et al. 2016 European Guidelines on cardiovascular disease prevention in clinical practice. Eur Heart J. 2016;37:2315-81.

5. Cooney MT, Dudina A, D'agostino R, Graham IM. Cardiovascular riskestimation systems in primary prevention: do they differ? Do they make a difference? Can we see the future? Circulation. 2010;122:300.

6. Damen JA, Hooft L, Schuit E, Debray TP, Collins GS, Tzoulaki I, et al. Prediction models for cardiovascular disease risk in the general population: systematic review. BMJ. 2016;i2416.

7. D'Agostino RB, Vasan RS, Pencina MJ, Wolf PA, Cobain M, Massaro JM, et al. General cardiovascular risk profile for use in primary care: the Framingham Heart Study. Circulation. 2008;117:743-53.

8. Conroy RM, Pyorala K, Fitzgerald AP, Sans S, Menotti A, De Backer $\mathrm{G}$, et al. Estimation of ten-year risk of fatal cardiovascular disease in Europe: the SCORE project. Eur Heart J. 2003;24:987-1003.

9. Woodward M, Brindle P, Tunstall-Pedoe H. Adding social deprivation and family history to cardiovascular risk assessment: the ASSIGN score from the Scottish Heart Health Extended Cohort (SHHEC). Heart. 2007;93:172-6.

10. Hippisley-Cox J, Coupland C, Vinogradova Y, Robson J, May M, Brindle P. Derivation and validation of QRISK, a new cardiovascular disease risk score for the United Kingdom: prospective open cohort study. BMJ. 2007;335:136.

11. Hippisley-Cox J, Coupland C, Vinogradova Y, Robson J, Minhas R, Sheikh A, et al. Predicting cardiovascular risk in England and Wales: prospective derivation and validation of QRISK2. BMJ. 2008;336:147582.

12. Jørstad HT, Colkesen EB, Minneboo M, Peters RJ, Boekholdt SM, Tijssen JG, et al. The Systematic COronary Risk Evaluation (SCORE) in a large UK population: 10-year follow-up in the EPIC-Norfolk prospective population study. Eur J Prev Cardiol. 2015;22:119-26.

13. Karjalainen T, Adiels M, Björck L, Cooney MT, Graham I, Perk J, et al. An evaluation of the performance of SCORE Sweden 2015 in estimating cardiovascular risk: the Northern Sweden MONICA Study 1999-2014. Eur J Prev Cardiol. 2017;24:103-10.

14. Hense HW, Koesters E, Wellmann J, Meisinger C, Völzke H, Keil

U. Evaluation of a recalibrated systematic coronary risk evaluation cardiovascular risk chart: results from systematic coronary risk evaluation Germany. Eur J Cardiovasc Prev Rehabil. 2008;15:409-15.

15. Direção-Geral da Saúde. Avaliação do risco cardiovascular SCORE: norma n. ${ }^{\circ}$ 005/2013, de 19/03/2013, atualizada em 21/01/2015. Lisboa: DGS; 2015.

16. de Oliveira Martins S, Silva PS, Papoila AL, Caramona M, van Mil JW, Cabrita J. Assessment of global cardiovascular risk and risk factors in Portugal according to the SCORE $®$ model. J Public Health. 2008;16:361-7.

17. Rocha T, Rocha E, Alves AC, Medeiros AM, Francisco V, Silva S, et al. Cardiovascular risk profile of high school students: a cross-sectional study. Rev Port Cardiol. 2014.33:525-34.

18. Tralhão A., Sousa PJ, Ferreira AM, Miranda M, Monge JC, Tomé A, et al. Cardiovascular risk profile of young adults: changes over time. Rev Port Cardiol. 2014;33:147-54.

19. Gouveia M, Rodrigues IP, Pinto D. Importância da validação dos modelos de risco cardiovascular nos cuidados de saúde primários. Rev Port Med Geral Fam. 2018;34:163-7.

20. Nunes B, Barreto M, Gil AP, Kislaya I, Namorado S, Antunes L, et al. The first design, planning and implementation. J Public Health. 2019;41:5117.

21. Tolonen H. EHES manual. Part B. Fieldwork procedures. Helsinki : National Institute for Health and Welfare ; 2013.

22. StataCorp. 2017. Stata Statistical Software: Release 15. College Station: StataCorp LLC; 2017.

23. Hagenaars A, de Vos K, Zaid M. Poverty Statistics in the late 1980s: research based on micro-data. Rotterdam: Office for Official Publications of the European Communities; 1994.

24. Amor AJ, Masana L, Soriguer F, Goday A, Calle-Pascual A, Gaztambide $S$, et al. Estimating cardiovascular risk in Spain by the European Guidelines on cardiovascular disease prevention in clinical practice. Rev Esp Cardiol. 2015;68:417-25.

25. Torlasco C, Faini A, Makil E, Ferri C, Borghi C, Veglio F, et al. Cardiovascular risk and hypertension control in Italy. Data from the 2015 World Hypertension Day. Int J Cardiol. 2017;243:529-32.

26. Podolecka E, Doryńska A, Nadrowski P, Skrzypek M, Kwaśniewska M, Drygas W, et al. Socioeconomic status and cardiovascular risk SCORE. Kardiol Pol. 2018;76:560-5.

27. Diederichs $C$, Neuhauser H, Rücker V, Busch MA, Keil U, Fitzgerald AP, et al. Predicted 10-year risk of cardiovascular mortality in the 40 to 69 year old general population without cardiovascular diseases in Germany. PloS one. 2018;13:e0190441.

28. Baena-Díez JM, Subirana I, Ramos R, de la Cámara AG, Elosua R, Vila $\mathrm{J}$, et al. Validity assessment of low-risk SCORE function and SCORE 
function calibrated to the Spanish population in the FRESCO cohorts Rev Esp Cardiol. 2018;71:274-82.

29. Van Dis I, Kromhout D, Geleijnse JM, Boer JM, Verschuren WM Evaluation of cardiovascular risk predicted by different SCORE equations: The Netherlands as an example. Eur $\mathrm{J}$ Cardiovasc Prev
Rehabil. 2010;17:244-9.

30. Lindman AS, Veierød MB, Pedersen JI, Tverdal A, Nøjlstad I, Selmer R. The ability of the SCORE high-risk model to predict 10-year cardiovascular disease mortality in Norway. Eur $\mathrm{J}$ Cardiovasc Prev Rehabil. 2007;14:501-7. 